\title{
Mathematical and Philological Insights on Cuneiform Texts. Neugebauer's Correspondence with Fellow Assyriologists
}

\author{
Christine Proust, CNRS \& Université Paris Diderot ${ }^{1}$
}

One of the most remarkable features of mathematics from ancient Mesopotamia and Egypt is that it has reached us from archaeological sources. We appear to have before us texts written and used by the ancient scholars themselves, and not, as is most often the case with texts transmitted through a long written tradition, which may have profoundly transformed the original work. Does this mean that historians of the ancient Near East have direct, unbiased access to the original ancient texts? It would be an illusion to believe this on at least two counts. First, archaeological sources themselves, including the oldest, are for the most part the result of textual transformation such as compilations, copies, translations, dictations, and many other processes, the history of which is difficult to reconstruct. Second, for the historian, access to his sources can only be gained through the mediation of the work of the scholars who made the texts available through process such as cataloging, copying, and editing. This chapter scrutinizes the effects of such intermediaries.

When reading an ancient text, we are deeply indebted to readings made previously by scholars who edited the texts and made them available. The process of decipherment, transliteration, translation, and commentary does not provide us with the raw material, but rather with interpretations of these texts. These reading keys are not always made explicit in the publications, but they appear more clearly in the editors' working documents, such as drafts, letters, annotations or notebooks.

In recent years, working documents produced and used by Otto Neugebauer when he was preparing the earliest editions of mathematical cuneiform texts became accessible to the researchers. These archives show how Neugebauer worked day by day and reveal the issues he faced while discovering cuneiform mathematics. Among Neugebauer's papers, his correspondence with other Assyriologists is of particular interest as it indicates how Neugebauer, a mathematician, benefited from the expertise of philologists either through deep friendship, such as with Albrecht Goetze and Abraham Sachs, or through competition as with François Thureau-Dangin. Thus, this documentation allows us to follow and to understand the project that led to the publication of Mathematische Keilschrifttexte (Neugebauer 1935-1937 MKT hereafter), and later Mathematical Cuneiform Texts with Sachs (Neugebauer \& Sachs 1945, MCT hereafter).

The aim of this chapter is to show some aspects of the impact of Neugebauer's work on our current understanding of cuneiform mathematics. The first part provides a brief overview of Neugebauer's papers relating to mathematical cuneiform texts. The second part

\footnotetext{
${ }^{1}$ I would like to thank my friend and colleague Françoise Rougemont for the time she spent with me studying the contents of the Neugebauer correspondence as well as his publications in German, and for her careful reading of the drafts of this article. Without this collaboration, the present chapter would not have been possible. The material used in this study was collected thanks to a grant offered by the Institute of Advanced Study (Otto Neugebauer Fund, fall 2009) and the Institute for the Study of the Ancient World, NYU (spring semester 2010). My deep gratitude goes to these two institutions, and thanks are especially due to IAS librarians, Christine Di Bella and Erica Mosner. I also warmly thank Ulla Kasten and Benjamin Foster who pointed out the interest of the correspondence between the Curators of the Yale Babylonian Collection and Neugebauer. This work benefited greatly from the enthusiastic support of the late John Britton, to whom I am immensely grateful.
} 
presents some examples showing how the works of Neugebauer and his close colleagues (mainly Goetze, Sachs and Thureau-Dangin) shaped the editions of cuneiform mathematics.

\section{Overview of Neugebauer's archives used in this chapter}

Neugebauer's papers are divided between several archives kept at Yale University, Institute for Advanced Study in Princeton, New York University, Brown University, Michigan University and other places in the United States and Europe. More details on the archives containing papers related to cuneiform mathematics are provided in the following.

\section{Yale Babylonian Collection (YBC Archives)}

The Yale Babylonian Collection includes archives, especially the letters exchanged by the Curators with scholars who worked on the tablets, as well as with dealers from whom tablets were purchased. These archives contain, among others items, two folders of interest for us: the correspondence with Neugebauer and with Sachs.

The "Neugebauer 1931-1957" folder contains 124 letters between the Curators and Neugebauer. They deal mainly with issues ranging from authorization for publication, to photographs of mathematical and astronomical tablets kept at Yale. Some of the letters also contain discussions on scientific issues, for example about how Babylonian mathematicians solved quadratic equations.

The "Sachs 1942-1955" folder contains 49 letters exchanged by the curator, Ferris J. Stephens, and Abraham Sachs, concerning the inventory, indexing, and photographs of the tablets kept at Yale.

\section{Yale University Library, Manuscripts \& Archives (YUL Archives)}

274 letters exchanged by Neugebauer (and sometimes Sachs) and Goetze are kept among the Manuscripts \& Archives of Yale University Library (Goetze 1929-1978, MS \# 648, box \# 15 - YUL thereafter). They deal with political, scientific as well as more personal topics. The political issues are related to the situation in Europe and the United States before and during World War II, the assistance offered to Jewish scholars dismissed from their positions in Germany ${ }^{2}$, the condition of immigrants from Europe in the United States, antiSemitism in American Universities and other matters. The scientific discussions focus on the mathematical tablets in the Yale collection, that is, the search for new texts, as well as on collations and philological assistance provided by Goetze to Neugebauer.

\section{The Shelby White and Leon Levy Archives Center, Institute for Advanced Study (IAS Archives)}

The Institute for Advanced Study in Princeton hosts the bulk of the personal library and papers left by Neugebauer. The collection was subsequently enriched by documents donated by Edward S. Kennedy, and later by John P. Britton on behalf of Asger Aaboe ${ }^{3}$.The

\footnotetext{
${ }^{2}$ Leo Oppenheim's escape, in particular, was a major concern for Neugebauer, and he worked hard to help Oppenheim emigrate to the USA.

3"Neugebauer left instructions that the bulk of his library be left to the Institute for Advanced Study for disposition after his death. The notebooks were found among the items in his library. He had previously donated the majority of the volumes of publications (library acquisition 84-B1019), with one small volume added by the Historical Studies-Social Science Library in 1993. The files related to Astronomical Cuneiform Texts and his
} 
Shelby White and Leon Levy Archives Center, created at the IAS in 2010 (Di Bella 2010), is now in charge of the preservation of the papers ${ }^{4}$.

Among the working papers, let us also mention the manuscript of Über vorgriechische Mathematik, written in 1934, and Babylonische Rechentabellen, undated (both available on the IAS website). Babylonische Rechentabellen is a 174 page typewritten document. It contains tables of calculation in sexagesimal place-value notation, necessary for the reading of cuneiform mathematical and astronomical texts. More than half of this document is devoted to reciprocal tables for 1, 2, 3, 4, 5 and 6 sexagesimal place-value numbers. The reciprocal tables are noted without using trailing zeroes or signs separating the fractional part. This important detail shows how Neugebauer used floating-point notation for recording data and, presumably, calculating, in a manner comparable to that of ancient scribes.

\section{Aaboe-Britton Archives}

Neugebauer entrusted some personal notes to Asger Aaboe, who himself later bequeathed them to John Britton, who in turn made them available to ISAW researchers and visitors during the 2009-2010 academic year. These archives consist of several hundred folders. Each folder is devoted to a single mathematical or astronomical cuneiform tablet and contains transliterations, translations, collations, photos, and sometimes relevant letters. There are 206 folders for mathematical tablets, covering almost all the tablets published in $M K T$ and $M C T$. Besides the items described above, these folders contain numerous collations provided by Goetze, as well as several originals of Goetze's letters, the carbon copies of which belong to YUL archives.

The main protagonists of the letters are Ferris J. Stephens, Albrecht Goetze, Abraham Sachs, and Otto Neugebauer. The discussions between them concern mainly photographs of the tablets, collations of the parts of the texts unclear in the photographs, for example of the signs written on the edges, and the problem of regional dialectal variations ("dialect business", to quote Goetze ${ }^{5}$ ). These discussions shed light on the major role played by Goetze in the edition of cuneiform mathematics. The scientific issues involved by the "dialect business" are of great importance for the history of science since they address the uniformity of mathematics in Mesopotamia. Before entering the very content of the letters, a short presentation of the main actors involved may be useful.

\section{The actors}

Raymond P. Dougherty was Curator of the Yale Babylonian Collection from 1926 to his death in 1933, an event referred to in several letters ${ }^{6}$. He succeeded Albert T. Clay, the

Copernicus notes were donated by John P. Britton on behalf of the family of Asger Aaboe in 2007. (Neugebauer had given the materials to Aaboe for disposition after his death.) The diary and correspondence with Edward S. Kennedy were donated by Kennedy in 1997." (IAS website http://library.ias.edu/finding-aids/neugebauer)

${ }^{4}$ Neugebauer's papers are divided into 14 boxes. The archives include notebooks, manuscripts and working papers related to his major publications, published articles, correspondence with Kennedy (1950-1990), as well as a diary that Neugebauer kept while in the Austrian army during World War I on the Italian front. The notebooks contain extremely thorough lecture notes taken by Neugebauer during mathematics seminars held in Göttingen, Graz and Munich between 1919 and 1926 (see D. Rowe's chapter in this volume).

${ }^{5}$ YUL, Goetze to Neugebauer, 1942/08/17, 1942/11/14 (see Appendix A-2). Note that the references to the letters are given in this chapter according to the following form: ARCHIVE, sender to recipient yyyy/mm/dd.

${ }^{6}$ Stephens to Neugebauer 1933/06/12, 1934/01/04; Neugebauer to Stephens 1934/01/31 (the latter letter is provided in Appendix A-1). 
founder of Yale Babylonian Collection (Curator 1910-1925). Ferris J. Stephens, Curator from 1933 to 1962, was Neugebauer's main interlocutor for everything concerning access to the tablets.

Albrecht Goetze (1897-1971) was Professor of Semitic Languages and Comparative Linguistics in Heidelberg from 1927 to 1930, Professor of Semitic Languages and Ancient Oriental History in Marburg from 1930 to 1933. In 1933, he was dismissed by the Nazi government as "politically unreliable." After a brief stay in Copenhagen and Oslo, he came to Yale University in 1934 as invited professor of Assyriology and was to stay with the Yale Babylonian Collection until he retired in 1965. We can follow through his letters to Neugebauer his adaptation to the American way of life and his long path from the precarious status of a recent immigrant to the highest academic positions in Yale University: William Laffan Professorship in 1936, Sterling Professorship in 1956. The correspondence between Goetze and Neugebauer is written in German until June 1940. From this date, only one year after Neugebauer's arrival in the U. S., the two German scholars communicated only in English. As noted above, the letters are of interest from many points of view: political, sociological and of course scientific. In the limited scope of this paper, only some of the scientific aspects are addressed. As we shall see later, Goetze played an essential role in the discovery and decipherment of mathematical texts in the Yale Collection. This role is little known since Goetze did not publish much on mathematical subjects. Besides his seminal contribution on dialects in $M C T^{7}$, the papers he wrote on subjects linked to mathematical texts are: "Numbers idioms in Old Babylonian" (1946), "A mathematical compendium from Tell Harmal" (1951); and, of course, a "Review of Mathematical Cuneiform Texts" (1948). Essentially, Goetze's contribution to cuneiform mathematics took the form of his close collaboration with Neugebauer. In fact, this collaboration had been imposed to Neugebauer by Ferris J. Stephens, who was then Curator, as a condition for permission to publish new texts (YBC Stephens / Neugebauer 1934/05/29, 1934/06/12, 1934/07/09 - see Appendix A-1).

This condition was warmly received by Neugebauer and Goetze who had known each other since 1929 at least (YUL Goetze 1929/05/18) and had followed parallel paths from their flight from Nazi Germany to their arrival at U.S. Universities, via Copenhagen. Goetze identified most of the mathematical texts in the Yale Babylonian Collection that Neugebauer later published (see for example YUL Goetze to Neugebauer 1942/02/04 in Appendix A-2). In addition, Goetze helped Neugebauer to address the philological difficulties the mathematician faced everyday, a role increasingly assumed by Sachs from 1941. The numerous collations made by Goetze on behalf of Neugebauer testify his tireless assistance. But Goetze's role was important on another level. As a specialist in Semitic linguistics ${ }^{8}$, he became expert in Old Babylonian dialects and applied his knowledge of Akkadian orthography and phonology to mathematical texts.

Abraham Sachs (1915-1983) met Neugebauer for the first time in 1941 while working at the Oriental Institute of Chicago on the Assyrian Dictionary. A few months later, the young Assyriologist became Neugebauer's assistant. ${ }^{9}$ Although Sachs' work is well known through

\footnotetext{
${ }^{7}$ Goetze 1945. In his review of $M C T$, Jacobsen (1946: 18) stresses the importance of this work: "Before concluding this review we would once more call the attention of Assyriologists specifically to Goetze's important contribution, chapter IV. The criteria for provenance of the tablets which he there establishes have a bearing far beyond the mathematical texts." We will come back on this essential point below in the section on "Dialect Business".

${ }^{8}$ Finkelstein 1972, p. 199.

${ }^{9}$ Swerlow 1993, p. 152: "Sachs was interested in Neugebauer's work, about which he already knew something, and he could read any text no matter how obscure or damaged. Neugebauer decided immediately that this was the person to continue the great project of publishing all the astronomical texts, and on the way back to Providence, he stopped in New York to discuss the matter with the Rockefeller Foundation. In the fall Sachs
} 
his own letters ${ }^{10}$, we don't have any letters between Sachs and Neugebauer. Of course, the daily contacts between the two friends explain this absence. But many letters found in the Goetze folder at Yale University Library are signed "MCT Inc.", meaning Neugebauer and Sachs. Moreover, "the Owl", nickname ${ }^{11}$ given to Sachs by Neugebauer, is omnipresent in Neugebauer's correspondence.

\section{Photo business}

Neugebauer's letters to Dougherty and Stephens include endless requests for photographs. His primary concern was the quality of the pictures. Neugebauer occasionally provided detailed technical advice on this matter (YBC, Neugebauer to Stephens 1934/01/31 see Appendix A-1 and Fig. 1).

\section{[Fig-1]}

His second concern resulted from the fact that clay tablets are tri-dimensional objects, unlike the flat surface of a book's pages. Thus, signs written on the edges of the tablets do not appear on the photos of the obverse or the reverse of the tablets. Consequently, Neugebauer often required additional images of the edges and suggested methods for improving the depthof-field of the photos.

Through these exchanges, we also follow in detail the stages of tablet restoration: cleaning, baking, and rinsing (YUL 1942/09/02 and 1942/09/11). This preliminary stage of editorial work is generally completely absent from publications.

The letters show how meticulous and precise Neugebauer was in his reading of texts. Any slightly obscure cuneiform sign was subject of long discussion by correspondence with his colleagues at Yale, and he did not hesitate to inundate them with relentless requests for collations. For example, the reading of YBC 7164 occupies most of the correspondence between Neugebauer and Stephens during the fall 1942 (letters dated 1942/09/22, 1942/10/13, 1942/10/27, 1942/11/03). Goetze was also involved: "Both Goetze and I examined the signs circled in red on your manuscript. We made our drawings independently and compared results only after both had completed the drawings. I am glad to see that we agree as to what is to be seen on the tablet." (YBC, Stephens to Neugebauer 1942/11/03). See Figure 2 below.

[Fig2a]

[Fig2b]

\footnotetext{
came to Brown as a Rockefeller Foundation Fellow with his wife Janet, who worked both at the university and at MR [Mathematical Reviews]. Then in 1943 Neugebauer received a ten-year grant from the Rockefeller Foundation, mostly to pay for a research associate, and Sachs became the Research Associate. And when the Department of the History of Mathematics was formed in 1947, Sachs joined the faculty, becoming an associate professor in 1949 and a professor in 1953. For more than forty years Sachs was Neugebauer's closest colleague and closest friend. While they collaborated on a number of publications, this in itself gives no idea of the depth of their working relation."

${ }^{10}$ Lieberman 1991.

${ }^{11}$ From 1946, Neugebauer and Goetze began to use nicknames: "Nujipuri", and "Elephant" for Neugebauer; "Hippopotamus", and sometimes "Rhinoceros" for Goetze (see for example YUL, Goetze to Neugebauer, 1946/06/22; Neugebauer to Goetze 1946/05/31, 1946/07/17). Neugebauer sometimes signed his letters with the picture of an elephant.
} 
One can imagine the time spent by all of them in the collective decipherment of tablets by correspondence. Thus, it is surprising that Neugebauer only rarely examined the tablets himself. While travel was impossible at the beginning of his collaboration with Stephens and Goetze when he was living in Europe, it was easy from the time he moved to Providence, which is only one hour by train from New Haven. He very rarely made this short journey. Neugebauer seems to have preferred to work on photos and leave the collations in the good care of his competent colleagues, perhaps, paradoxically, due to his concern for detail and accuracy. However, the habit of working only on photographs had some drawbacks, as Goetze sometimes kindly remarked to his friend: Obviously the photograph did fool you. (YUL, Goetze to Neugebauer 1943/01/21 - See complete letters in Appendix A-2). Indeed, it could happen that the photograph "fooled" Neugebauer for the reading not only of individual signs, but also for entire sections. In a few cases, bracketed text in transliteration (that is, text considered as damaged by Neugebauer) is in fact perfectly preserved. Examining the photos used by Neugebauer, which are mostly kept in the Aaboe-Britton folders, one realizes that a "damaged text" for Neugebauer may often simply be a blurred photo (see YBC 4710 \#4 in Appendix B-1). In other cases, the blurring of the photo combined with some dirt pasted on the clay surface make the text almost unreadable, although the tablet is currently in perfect condition (see YBC 4668, \#33 in Appendix B-2). It is interesting to note that the unnecessary brackets are found at the same place in Thureau-Dangin's transcriptions. This detail proves that Thureau-Dangin used the very same photographs as Neugebauer (see Appendix B-2 and B-3).

Comparing the text of "damaged" sections restored between brackets by Neugebauer and the actual text on the original tablet shows how deep his understanding of the texts was. Indeed, in most of the cases, the restoration by Neugebauer is correct. However, in some exceptional cases, such as YBC 4710 \#4, a new reading can restore crucial information and improve the interpretation notably (see Appendix B-1). ${ }^{12}$

Beside the daily work on the tablets, the correspondence sheds light on scientific discussions between Neugebauer and the Assyriologists which are of great interest in the history of ancient mathematics. A good example is a long explanation by Neugebauer in reply to a question by Stephens: "did the ancient scribes really solve the equations, or did they simply guess the solutions by trial and error?". Another example, on which the following section focuses, is a discussion on the dialectal variations in mathematical texts. This discussion should become an additional chapter of $M C T$ written by Goetze.

\section{Dialect business}

Beyond philological assistance to Neugebauer, Goetze's contribution to the history of mathematics is crucial for he demonstrated the existence of dialectal differences within the Old Babylonian mathematical corpus.

In 1942, Goetze writes to Neugebauer in a post scriptum:

Did I ever tell you that the mathematical tablets in Old Babylonian can be divided in a northern and a southern group on linguistic grounds? The evidence in most cases confirms the information as to provenance given by the dealers from whom the tablets were purchased. (YUL, Goetze to Neugebauer 1942/02/04 - see complete letter in Appendix A-2)

Neugebauer immediately shows his interest:

\footnotetext{
${ }^{12}$ This is also the case for tablet YBC 4696: Neugebauer used a poor photograph, and actually, the reading of the text can be improved by examining the original tablet.
} 
You never mentioned anything about the dialect in the mathematical texts. This interests me of course very much, and I hope to hear more when I am down at Yale. (YUL, Neugebauer to Goetze 1942/02/10)

However, Neugebauer and Sachs underlined the difficulty of the project as far as the Yale tablets were concerned, since most of them are catalogues and series texts written with Sumerograms and use very few syllabic notations of Akkadian words.

... we are herewith taking advantage of your kind affirmative answer to our request to look at the dialect(s) of our new Akkadian mathematical texts. Enclosed are the transcriptions of YBC 4608, 4662, 4663, and 4675, the only texts written in Akkadian except for the Plimpton tablet, on which the only two Akkadian words we can read with certainty are și-li-ip-tim and [in]-na-as-sà-hu-ú-[ma]. (YUL, MCT Inc to Goetze1942/08/01 - See complete letter in Appendix A-2)

Some nine months after announcing his idea to Neugebauer, Goetze details the method he intends to use:

The right procedure, I feel, would be this: numerate the characteristics which allow the classification (giving a number to every item). Then, listing the signature of the texts and adding the number of the characteristic with the necessary references. (YUL, Goetze to Neugebauer 1942/11/14)

He completed the work in a short time since, as early as January 21, 1943, he announces to Neugebauer and Sachs:

I have just typed a 14 page statement concerning the "dialect" of the mathematical tablets. It needs going over and checking and will then be mailed together with your manuscript. (YUL, Goetze to Neugebauer and Sachs 1943/01/21)

A couple of days later, Goetze sent the manuscript to Neugebauer, but not without expressing some reservations about the results:

Here enclosed you will find the statement on the "dialects" of the mathematical tablets which I promised you some time ago. At the same time I am returning the pages of your manuscript which you so kindly placed at my disposal.

Not that I am entirely satisfied with the result. You will see that I felt compelled to attempt some grouping of the texts. On this point I expect your criticisms. It is my feeling that I rather encroached on your domain. I would feel much better, if you could be persuaded to handle this subject in a special chapter which should precede mine. As it is, I could give only some hints in footnotes. You have expressed yourself the intention of doing some grouping at the head of your glossary. And I think the subject calls for some fuller treatment. (YUL, Goetze to Neugebauer 1943/01/25 - See Appendix A-2)

Neugebauer and Sachs' reaction is extremely interesting in that it reveals an appreciation of the diversity of cuneiform mathematics quite different from Goetze's (the following is an extract, but the whole letter deserves reading - see YUL, MCT Inc. to Goetze 1943/02/17; note that the letter is erroneously dated 1942 by the author).

As you know, we are unable to establish any local distinction in our material -[...]. It is therefore of great interest to learn that a clear "southern" group can be isolated. Unfortunately, we cannot contribute anything to this view of yours from the point of view of content. Our arrangement (A, B, C, D, etc.) is purely arbitrary according to content e.g., geometrical problems, irrigation problems, etc. The more material we get, the more we begin to realize to how great an extent we are at the mercy of the accidental character of the excavation and preservation of our texts. Grouping which seemed to be quite reasonable in MKT (e. g. "series texts") disappear more and more. All we can say at present is that the content of the Old-Babylonian mathematical texts is so homogeneous and uniform that from this point of view one cannot make any classification with regard to origin or time (of course, the clear distinction from Seleucid material remains). (See complete letter in Appendix A-2)

'Goetze's analysis of dialectal variations opened perspectives that Neugebauer and Sachs had not considered, convinced as they were that cuneiform mathematics was highly homogeneous and probably came from very few different centers producing cuneiform mathematics. The geographical and chronological variations were not taken in account in $M C T$. Indeed, the organization of MCT does not reflect Goetze's groups in any way. Neugebauer and Sachs 
decided to publish Goetze's contribution in a separate chapter that would not affect the organization and content of the rest of the book. It is surprising that Neugebauer and Sachs did not say anything in $M C T$ on their opinion of Goetze's point of view, despite an express request from the latter (I would feel much better, if you could be persuaded to handle this subject in a special chapter which should precede mine - Goetze in the letter of 1943/01/25 cited above). This silence by Neugebauer and Sachs might reveal a lack of confidence concerning the difficult problem of the uniformity of cuneiform mathematics, on which they seem to have more convictions than strong arguments, or simply a reluctance to disagree publically with their friend Goetze.

Today, this decision might seem amazing. Indeed, Goetze's chapter on dialects turned out to be a seminal work that has not been surpassed, and still remains a landmark for Assyriologists. After World War II, the discovery and publication of mathematical texts from Ešnunna, a city located in the northern part of Mesopotamia, and from Susa, in western Iran, provided new evidence showing the diversity of Old Babylonian mathematics. In modern historiographical trends, a greater sensitivity to the diversity of mathematical cultures is observed. Goetze's groups provided a solid basis for the studies on cuneiform mathematics, particularly the work on mathematical cultures in Mesopotamia by Høyrup and Friberg ${ }^{13}$.

Several reasons explain Neugebauer and Sachs's decision not to use Goetze's groups to reorganize $M C T$. The first and most evident is that $M C T$ was almost finished when Goetze sent his chapter to "MCT Inc." The end of 1942 was devoted to corrections of MCT, and most of the letters between Yale and Brown focused on corrections of the final manuscript. The second reason is, as stated by Goetze himself, that the dialectal groups could not include all of the tablets since the texts written with sumerograms, namely most of the Yale sources, could indeed not be analyzed on the basis of Akkadian dialects. The third and more fundamental reason is Neugebauer and Sachs's conviction that Old Babylonian mathematics was strongly homogeneous. Indeed, when Goetze proposed his project to them, they did not believe that the results would change their perception of things. Their favorable welcome to the "dialect business" seems to have been more polite than enthusiastic. The correspondence between 1942/02/04 and 1943/01/25, focused on correcting MCT, does not show excessive concern from Neugebauer and Sachs about the potential results of Goetze's investigations on dialects.

In order to understand Neugebauer and Sachs' view, we have to keep in mind that a striking feature of Old Babylonian mathematics is the standardization of the metrological systems. This feature gives the mathematical texts an apparent unity. But the uniformity of notation is the result of the relative uniformity of education in the scribal schools, which, during the Old Babylonian period, formed a dense network, spread out over a large part of the Ancient Near East ${ }^{14}$. Onto this common elementary knowledge, shared by the erudite scribes in Mesopotamia and beyond, were grafted specific scholarly traditions which could differ deeply one from the other. In a way, with their opposite views, Neugebauer and Goetze were describing different aspects of the same complex realia.

\footnotetext{
${ }^{13}$ Høyrup 2000, 2002: ch. 9 and Friberg 2000.

${ }^{14}$ Old Babylonian scribal schools have been the subject of many studies; see for example Veldhuis 1999 with its bibliography.
} 


\section{Neugebauer and Thureau-Dangin: A mathematical approach versus a philological approach?}

In the correspondence between Neugebauer and Goetze, we see with great precision how the mathematical and philological skills of two scholars with completely different backgrounds were able to complement and inspire each other and to produce editions of texts of outstanding quality that has not been surpassed since.

The cooperation between Neugebauer and Thureau-Dangin was of a quite different nature. The Yale correspondence echoes the tensions between the two prominent specialists of cuneiform mathematics:

With surprise and honest regret I have come to know that a certain animosity has developed between
Thureau-Dangin and yourself. Personally, I feel it is most unfortunate since I have always treasured
Thureau-Dangin and never had the slightest reason to doubt his excellent character. Isn't this a rare case
among Assyriologists. It almost seems as if Assyriology ruins one's character! (YUL, Goetze to
Neugebauer 1937/02/14 - See complete letters in Appendix A-3).

This animosity probably goes back to some months (see Appendix A-3). During the spring of 1936, Stephens asked Neugebauer for permission to send the photos of the tablets to ThureauDangin, who was willing to "check" his transliterations and translations (YBC, Stephens to Neugebauer 1936/04/03, 1936/06/16 - See complete letters in Appendix A-3), probably for his review of $M K T$ I (Thureau-Dangin 1936). It is easy to understand that Neugebauer was not very happy with this request. In his reply, three months later, the competition between the two scholars became even more apparent (YBC, Neugebauer to Stephens 1936/06/27 - See complete letters in Appendix A-3).

As a matter of fact, Thureau-Dangin subsequently extended his project beyond his initial plan to "check" Neugebauer's work. He published Textes Mathématiques Babyloniens (hereafter $T M B$ ) in 1938, which is not far from being a re-edition of the texts published in $M K T$, where the French Assyriologist corrected and substantially improved the readings by Neugebauer. ${ }^{15}$ These improvements had been listed in detail in his quite critical reviews of MKT (Thureau-Dangin 1936, 1937). But it is clear that Thureau-Dangin was fully confident in Neugebauer's understanding of the mathematics: L'interprétation mathématique est, dans l'ouvrage de N. [MKT I], beaucoup meilleure que l'interprétation philologique. L'auteur est là sur son terrain. (Thureau-Dangin 1936: 59) ${ }^{16}$. The philologist did not change the meaning of the texts, except for two texts (Str. 362 and VAT 8528), in which he corrected the mathematician on his own ground (Thureau-Dangin 1936: 59-60). An important consequence of this story is that $M K T$ and $T M B$ have become inseparable. Today scholars cannot use $M K T$ without, at the same time, also referring to $T M B$, and vice-versa.

Thureau-Dangin read the tablets from the photos sent to him by Stephens, who is warmly thanked in many footnotes in $T M B$, and he used the same material as Neugebauer. Thus, the uncertain readings due to a blurred picture in $M K T$ remain uncertain readings between brackets in $T M B$, as already noted above and in Appendix B.

The difficult but fruitful cooperation between Neugebauer and Thureau-Dangin upsets simplistic ideas whereby mathematicians are only capable of mathematical understanding, and philologists of philological insight. Neugebauer and Thureau-Dangin's case shows an

\footnotetext{
${ }^{15}$ It seems that the "animosity" between the two scholars was to spread later. In his Hommage à la mémoire de l'éminent assyriologue François Thureau-Dangin, Edouard Dhorme presents TMB as an ouvrage unique au monde without any word on the work of Neugebauer.

16“"The mathematical interpretation in N's work [MKT 1] is much better than philological interpretation. The author is more at home".
} 
interesting reversal of roles. As early as 1932, Neugebauer criticized the transcription system used by Thureau-Dangin:

\begin{abstract}
"While the transcription system of numerals is merely a matter of convention, the question concerning the transcription of ideograms of mathematical expressions belongs to the field of philology, where a solid tradition has been established. I am aware, that with the following I am going against the opinio communis, but nonetheless would like to open a discussion, which to me seems factually important.
\end{abstract}

An example. Thureau-Dangin transcribes (a) GAM (b) DU-ma with (a) adi (b) tubal-ma. One is to note here: why the second person and not the imperative? Both are used in mathematical texts, and the selection concerning $D U-m a$ is merely arbitrary (same goes for the verb forms, I or II and the like). Why $D U=a b a \hat{l} u$ and not for example = šakânu (the latter being frequently used in mathematical texts)? And similar questions occur in other cases.

\begin{abstract}
The matter touched upon here is not negligible but a totally essential point. First, one can no longer conclude which symbol was written in the text from the transcription (a fact which could be significant in the case of questions concerning how to put together certain text groups ${ }^{17}$ ). Furthermore, how should one to proceed if entire Sumerian phrases are contained in Akkadian texts? Why should one Akkadize them? By the same rule, one would eradicate the Latin and French in essentially German writings of scholars of the $17^{\text {th }}$ century. And finally, with the process of Akkadization one destroys the fundamental role of the ideograms: namely that they function entirely like mathematical symbols and that the Akkadization essentially does the same as the substitution of e- $\mathrm{x}^{2}$ with "e-superscript-minus- $x$-squared" or (because one generally does not know how to pronounce such a symbol) the fabrication of a "real" grammatical sentence. The engagement with this text genre made it more and more apparent to me that the ideograms play a crucial role for the remarkably strong algebraic character of Babylonian mathematics (if originally intended or not is not of importance in this instance)." (Neugebauer 19321933: 222- Translated in English by Sandra Hoehn)
\end{abstract}

In fact, the Akkadization of the transcription by Thureau-Dangin (see examples in Appendix B) did not generally hide the original ideograms, since he used different transcriptions for Akkadian words noted phonetically in the tablets, and Akkadian words corresponding to ideograms. The original ideogram could be identified thanks to his "Lexique" (TMB, p. 215243). However, as noted by Neugebauer, this Akkadization could sometimes be ambiguous and, more seriously, could hide specific mathematical meaning conveyed by ideographic writing. This issue is particularly marked for texts that use Sumerograms almost exclusively, such as series texts. In this matter, Neugebauer's philological sensitivity is obvious, and subsequent philological tradition was to prove him right. ${ }^{18}$

For his part, Thureau-Dangin showed a remarkable acuteness in understanding the nature of the numbers used in mathematical cuneiform texts. As early as 1930, he offered a penetrating analysis of cuneiform sexagesimal place value notation. ${ }^{19}$ This work was followed by his seminal Esquisse d'une histoire du système sexagésimal $(1932)^{20}$, where interesting parallels are drawn between Babylonian abstract numbers and new concepts of numbers introduced by mathematicians Simon Stevin (1548-1620) and John Wallis (1616-1703). He suggests that the sexagesimal place value notation, which includes both integers and fractions in a unified system, and was used in astronomy in early modern Europe, may have inspired Simon Stevin's generalization of decimal place value system. Referring to "Cantor, Vorlesungen über Gesch. D. Math. $1^{e}$ éd. II, p. 563 ss.", he states:

\footnotetext{
${ }^{17}$ I guess that by "groups of texts" (Textgruppen) Neugebauer refers to the series texts that he labeled "Serientexte" in further publications.

${ }^{18}$ As an evidence of the great influence of the French assyriologist, we must observe that for mathematical texts, Goetze used Thureau-Dangin's method of transcription, and not Neugebauer's (Goetze 1951).

19 Thureau-Dangin 1930.

${ }^{20}$ See Høyrup's chapter, section on sexagesimal place value notation. In 1939, Thureau-Dangin published Sketch of a History of the Ssexagesimal System, an English version of Esquisse (Thureau-Dangin 1932). Analyzing both versions shows that the publication of MKT in 1935 slightly modified his approach to metrological tables.
} 
The Hindu system concerned itself only with the expression of the integers. The Babylonian system, which assimilated the integers and the fractions, emanated from an extremely wide and comprehensive conception of the number. The idea of applying to the fractions the same progression as to the integers, but in decreasing order, has not been realized in our system of numeration prior to the dawn of the modern times. Simon Stevin was the first to give a clear exposition of it in a treatise published by Plantin, at Leyden, in 1585, under the title: "La Disme, enseignant facilement expedier par nombres entiers sans rompuz, tous comptes se rencontrans aux affaires des Hommes."21

Thureau-Dangin's deep understanding of numbers by is probably related to the fact that he gave great importance to metrological texts, which were discarded by Neugebauer as not "really mathematical". The study of Mesopotamian metrology is one of the most important of Thureau-Dangin's works. His earliest papers deal with these topics (see ThureauDangin 1893, 1896), as do most of his articles published between 1928 and 1934. Conversely, Neugebauer constantly insisted on the fact that he was not interested in metrological lists and tables, which nevertheless were to appear later as an essential component of mathematical education in Old Babylonian scribal schools. ${ }^{22}$

As we see, in some cases, deep mathematical sensitivity came from Thureau-Dangin, the philologist, and rigorous philological methodology from Neugebauer, the mathematician.

\section{Toward other horizons}

This selective review of Neugebauer's correspondence underlines the collaborative aspects of the work which was to lead to the publication of MKT and MCT. Thanks to Neugebauer's scientific rigor and his ability to work collectively, a set of highly reliable sources are available for research. However, scrutinizing the way these sources were shaped allows us to use them in a critical way. For example, as already said, we cannot work with $M K T$ without using also TMB. The fact that Neugebauer (and, to some extent, ThureauDangin) had access to the tablets almost exclusively through photographs should encourage the modern researchers to examine, as far as possible, the original tablets.

Neugebauer was interested essentially in the publication of primary sources. As his energy was mobilized mainly by the search for new texts, he never returned to them once the mathematical cuneiform texts had been published. He opened extremely fruitful avenues of research, such as exploring and using ancient systems of classification of mathematical material (YUL, Neugebauer to Goetze 1935/03/26). However, he did not follow them through, and his ambitious program still awaits completion, as if he had left the work of deeper interpretation to future generations. He somewhat abandoned the history of mathematics in 1945, after the publication of $M C T$, to devote himself to astronomy.

\footnotetext{
${ }^{21}$ Thureau-Dangin 1939, 140-141. The original French version (Thureau-Dangin 1932, 80) is: Le système Indou, tel du moins que nous l'avons emprunté, ne concernait que l'expression des entiers. Le système babylonien, qui assimilait entiers et fractions, procédait d'une conception du nombre autrement large et compréhensive. L'idée d'appliquer aux fractions la même échelle qu'aux nombres entiers n'a été réalisée dans notre système de numération qu'à l'aube des temps modernes. Simon Stevin l'a, le premier, clairement exposée dans un traité imprimé à Leyde, chez Plantin, en 1585, sous le titre : "La Disme, enseignant facilement comment expedier par nombres entiers sans rompuz, tous comptes se rencontrans aux affaires des Hommes. ».

${ }^{22}$ See for example letter YBC, Neugebauer to Stephens 1934/01/31 in Appendix A-1 where he describes the texts he is interested in, excluding metrological lists and tables. Similar claims can be found in many other letters (among them: YBC Neugebauer to Stephens 1932/08/12, 1934/07/27, 1935/05/31, 1935/12/28). Neugebauer tried to entrust metrological matters to Sachs (YUL Goetze to Neugebauer, 1945/01/22, Neugebauer to Goetze 1945/04/02). For more developments on the opposite approach of metrological texts by Thureau-Dangin and Neugebauer, see Proust 2010.
} 


\section{Appendix A: Letters}

German letters were translated in English by Sandra Hoehn.

\section{1- Photo Business}

\section{YBC, Neugebauer to Stephens 1934/01/31 (in German)}

Copenhagen, January 31, 1934

Dear Professor Stephens,

I would like to thank you for your letter of the 4 January and much to my honest regret, I was sorry to hear of the passing of Professor Dougherty.

The matter of the photographs of your collection was kindly arranged by Professor Flexner, New York, and led Professor Dougherty to provide me in 1932 with photographs of mathematical texts of his collection. These photographs are important for my entire enterprise on mathematical cuneiform texts. Thus far, he has forwarded me photographs of the following: YBC 4692, 4709, 4710, 4713 and promised me to send me further texts, which unfortunately did not happen due to his illness. At the time, he sent me three types of texts as photographs in order for me to ascertain which ones are important to me. They are the following: 1. metrological texts (several lists of measures such as YBC 4701), 2. multiplication and division tables such as YBC 4692, 3. purely mathematical texts such as YBC 4709/10/13.

Of these types of texts only the last two are of interest to me, while there are also texts which could be grouped in the first as well as the second type; these are needless to say also important to me.

Considering the still relatively small number of mathematical texts compared to the rest of the cuneiform literature, it is of the utmost interest to me to become familiar with even the smallest and poorly preserved fragments. Based on purely mathematical reasons, which I cannot explain in few words, I find even the seemingly straightforward tables interesting (if you are interested in peculiarities, maybe I can direct you to my research on the "Sexagesimal and Babylonian Fractions 1 to 4" in "Quellen und Studien zur Geschichte der Mathematik B 1 und 2").

I would be very grateful if you could ensure that the photographs also contain the text margins and, if possible, include a scale. Furthermore, I would like to ask you not to mount the photographs. It goes without saying that I am prepared to pay the costs for the photographs and I would like you to inform me about this.

I hope I am not causing you too much inconvenience with my requests and would like to take the liberty to add another. Could you please get the photographs prepared soon, since I am quite advanced in my work and would shortly like to reach a relatively final overview of the material. It may be interesting for you to know that the Yale texts YBC 4709/10/13 especially represent a new and very interesting type of text (systems of quartic equations) and it is thusly of the utmost historic interest to find out how the other texts from your collections are to be classified in respect to this group. 
I am looking forward to hearing from you again and would like to thank you once again for your kind efforts.

My warmest regards,

Yours respectfully

P.S. Certainly Professor Flexner will be willing to offer more information. Hence I am taking the liberty of sending him a copy of this letter.

\section{YBC, Stephens to Neugebauer 1934/05/29}

New Haven, May 29, 1934

Dear Professor Neugebauer:

After considering from every angle the question of your publishing our mathematical texts, I may now give you the following decision. You have my permission to make full use of the photographs which Professor Dougherty sent to you. They may be published in transcription, translation, autographed copied and photographic reproduction, if you desire. After examining the rest of the mathematical texts in our Collection it is very obvious that Professor Dougherty selected the best one to be photographed. Seeing that you have had some difficulty in reading even these photographs, I am sure that the majority of the texts could not be satisfactorily read from photographs without the help of someone who could have direct access to the tablets themselves. I do not feel like assuming full responsibility for doing the work that would be necessary in collating and copying many of these tablets. If you could find it possible to come in person to New Haven to study our texts at first hand I should be very glad to place them at your disposal. If this is not possible I have one other suggestion. You probably know that Professor Albrecht Goetze is to be Visiting Professor of Assyriology at Yale University next year. It has occurred to me that you may be able to secure his consent to give you the necessary assistance in handling these texts. I suggest that you get in touch with him at the following address: Esperance Alle 18, Kobenhavn-Charlottenlund. If he is willing to give you the assistance you will require I shall give my consent to the full use of all of the texts. Otherwise it seems to me that the balance of them should be reserved for publication by someone who have direct access to the tablets themselves.

I am returning to you herewith the copy of your manuscript which you kindly sent to me some time ago.

Yours very sincerely,

Ferris J. Stephens, Acting Curator

\section{YBC, Neugebauer to Stephens 1934/06/12 (in German)}

Copenhaguen, June 12, 1934

Dear Professor Stephens,

Thank you very much for your letter of the 29 May and the return of my manuscript. Moreover, I would like to thank you for putting the photographs, which are already in my possession, at my disposal and for allowing me to work on further mathematical texts. Personally, I know Professor Götze very well. By this time he is writing to you of his 
commitment to support me in the collation of problematic parts of the text as well as in any other way possible.

From a purely technical point of view, I would like to make the proposition that at this stage you already procure photographs of the texts in questions. It would very much facilitate and accelerate my work if I could already begin the preparatory work. In addition, it would allow me to discuss fundamental questions with Professor Götze as long as he is still here. Needless to say, I am intending to wait with any kind of publication until Professor Götze is in New Haven. I am convinced that this proposition raises no concerns, the more so because photographs of these texts are without doubt required for a general examination of the condition of the texts.

My warmest gratitude for your endeavours,

Yours respectfully

\section{YBC, Stephens to Neugebauer 1934/07/09}

New Haven, July 9, 1934

Dear Professor Neugebauer,

Since I have received your letter of the 12th of June and that of Prof. Götze of the 16th of June, in which he promises to help you with the necessary collations of our mathematical texts, I have had photographs of six additional tablets made. There are still several others which have not been photographed. I shall have them done and sent to you later. I have not sent them all at once for two reasons. First, I wish to learn if you have any suggestions concerning the technique of photographing. Second, some of the remaining tablets are in need of cleaning and perhaps baking. This will require some time. You perhaps realize that in the process of baking and cleaning tablets some damage may result to the tablet in spite of all the care we can exercise. In cases where I think it is necessary to bake a tablet do you wish to go to the additional expenses of having photograph made both before and after the baking process?

There will be no expense to you for the baking and cleaning of tablets, of course. We shall charge you only for the photographs. You need not pay for these until you have received all of them. The photographs which I am sending you today have been made at a cost of $\$ 10.00$. I have a record that Prof. Dougherty once sent you photographs costing \$5.00. This makes $\$ 15.00$ in all.

Trusting that you will find these new photographs satisfactory, I remain,

Yours very sincerely

Ferris J. Stephens

Acting Curator

\section{2- Dialect Business}

\section{YUL, Goetze to Neugebauer 1942/02/04}

February 4, 1942

Dear Neugebauer: 
The mathematical tablets newly found among the unbelievable richness of our collection number eight (tables excluded). It may well be that I have still overlooked one or the other piece. It is not easy task to go through unclassified material and picks out what you are looking for. So this will be for the present the best I can do for you. The tablets are in relatively good condition. Photographs have been already been taken. Stephens will take care of cleaning and baking as soon as possible. After that new photographs may be taken, or you may come down personally to make a collation.

The tables are less exciting. I think they can wait until you come down for your lecture.

I am sorry that the oriental Club cannot take advantage of your coming. But it was only a very slight chance anyway. Have provision be made for living quarters? If not, don't forget that my house is always at your disposal. This is valid also for Sachs, if he should like to accompany you.

Cordially yours

Did I ever tell you that the mathematical tablets in Old Babylonian can be divided in a northern and a southern group on linguistic grounds? The evidence in most cases confirms the information as to provenance given by the dealers from whom the tablets were purchased.

\section{YUL, Neugebauer and Sachs to Goetze 1942/08/01}

Providence, August 1, 1942

Dear Goetze:

We hope this finds you recuperated from the Summer Session of the Linguistic Society because we are herewith taking advantage of your kind affirmative answer to our request to look at the dialect(s) of our new Akkadian mathematical texts. Enclosed are the transcriptions of YBC 4608, 4662, 4663, and 4675, the only texts written in Akkadian except for the Plimpton tablet, on which the only two Akkadian words we can read with certainty are și-liip-tim and $[i n]-n a-a s$-sà-hu-ú-[ma]. In the enclosed transcription please disregard all underlining, since we used some of the carbon copies to make a vocabulary and underlined words to make sure that we didn't miss any.

We also hope you won't mind settling a friendly dispute which has arisen between us. Enclosed on a separate sheet is a translation of the first five lines of YBC 5037. One of us wishes to delete all the words which are in red, the other to keep them. We have decided to abide by your decision as to which of the two translations you would like to read.

We are waiting for several months now with bated breath for the new photographs of the Yale texts while the draft creeps up relentlessly toward one of us and while the other one is being loaded with more and more University duties. Stephens wrote us some weeks ago that the photographs had long been taken but the photographer did not have the time to make the prints. If you, with your usual discretion, could hurry this up, we would be very grateful. Cordially

MCT Inc.

For your convenience, the following numbers are the pages on which the beginnings of the transcriptions of the Old-Babylonian Akkadian texts will be found: 
MKT I: 108, 124, 126, 137, 143, 194, 219, 239, 244, 248, 257, 259, 267, 269, 270, 274, 278, 287, 289, 294, 303, 311, 314, 317, 319, 335, 341, 346, 351, 353, 368, 373, 516.

MKT II: 37, 43, 60.

MKT III: 1, 22, 29.

\section{YUL, Goetze to Neugebauer 1942/11/14}

November 14, 1942

Dear Neugebauer,

I had your letter concerning my contribution to your and Sachs' Mathematical texts.

I am quite willing to make good promise, but I am afraid I can hardly do before the Xmas recess. There are too many various things whirling around us to make possible the necessary concentration on that task. Furthermore, if I do it, would not it be advisable to include all the texts you are going to publish and not merely the four texts the notes on which you are returning to me? This would mean that I need your transliterations of all those texts (at any event the transliteration of YBC 4675, 4608, 4662, and 4683).

The right procedure, I feel, would be this: numerate the characteristics which allow the classification (giving a number to every item). Then, listing the signature of the texts and adding the number of the characteristic with the necessary references.

Stephens has to go to Indiana suddenly in family affairs (nothing tragic), and may thereby have been prevented from mailing the photos as he intended to. He will be back next Tuesday, and I shall talk to him as soon as I see him. I have seen the copies and they were very good indeed.

Let me know your decision on the dialect business.

Cordially yours

p. 2

$\underline{\underline{\text { YBC } 4663}}$

Southern Old Babylonian (mimation inconsistent):

$\mathrm{PI}=$ pi / e: né-pe-šsu (obv. 6, 13, 19, rev. 25) ; hé-pe (rev. 7, 19)

DU = țì: $\quad$ pu-ṭù-ur (obv. 9, 22, 24, 30, rev. 3).

ZU = sú: ú-sú-uh (rev. 9).

For $\mathrm{AZ}=$ ús see remark to YBC 4662.

p. 3

$\underline{\text { YBC } 4675}$

Southern Old Babylonian:

PI = pe: $\quad$ te-he-pe-e-ma (obv. 8, rev. 9). 
$\mathrm{DA}=$ ța: $\quad$ ta-pa-ța-ar (obv. 9, rev. 10).

ZA = sà: $\quad$ sà-ni-iq (obv. 7, rev. 6, 16).

Complement in a.šà-lam (obv. 3).

Repeated vowel for simple length : zu-ú-uz (obv. 3), ga-me-ru-ú-tim (obv. 7), ki-la-a-al-le-een (obv. 8). Also ša-ni-i-tim (obv. 5), [a-ra-ka-re-e-em (rev. 2, 12).]

Nazalization in i-na-an-di-kum (obv. 11, rev. 1).

$\underline{\underline{\text { YBC } 4608}}$

Southern Old Babylonian (mimation inconsistent):

$\mathrm{DA}=$ ța: $\quad$ i-pa-at-ṭa-ar (obv. 16), ip-pa-at-ṭa-ar (rev. 18).

Repeated vowel in a-ma-ri-ka (obv. 22, 28).

Construction aššum...amāri-ka (obv. 21f., 28).

For mali cf. TCL XVII 5837 ; XVIII 117, 8 ; UMBS VIII 2125 11) ; TS 712 (all southern); but also CT VIII 38a etc.; 50d 10; YBT II 4222 (northern).

\section{$\underline{\mathrm{YBC} 4662}$}

Southern Old Babylonian (mimation inconsistent):

PI = pí/e: hé-pe (obv. 17, 30).

Peculiar the employment of AZ in hu-ru-úș (obv. 22, 34) which recurs in YBC 4663 [...] and in AO 8862 [MKT II Taf. 35 ff.], both southern texts.

[Fig3a]

[Fig3b]

January 21, 1943

Dear Neugebauer and Sachs,

I have just typed a 14 page statement concerning the "dialect" of the mathematical tablets. It needs going over and checking and will then be mailed together with your manuscript.

You did not answer my last question: namely whether in Stbg. 366 obv. A reading sa-am-daka-am "triangle" makes sense.

I have include a short note on ki-i a-a in my manuscript. I certainly shall take no offense, if you are not convinced.

E [YBC 8633]. Rev. 9: I am reading now i-ta-di-... (perhaps -kum after all). You remember that the whole thing is corrected and partially squeezed in. The [...] form agrees with the same form in VAT 8512 which belongs in the same group because of concidences in terminology etc. The same form should also be restored in rev. 7 (and obv. 13?). 
L [YBC 7164]: I took another look at the alleged te-er-di-it-sà and also had Stephens look at it. We both agree that the correct reading is te-er-di-iz-za. The iz has the same dimensions as in is-sú-uh (1. 18) and is markedly different from the it in ú-sa-mi-it (11. 22, 24). [...] iz signs are quite normal in this period. When you look up Fossey you will sign that originally the sign was rather wide and became gradually narrower. Moreover te-er-di-it-sà is (as far as I can judge) an "Unform" in OB.

M: eh-re-e is necessary just as ep-te-e and el-qé-e among other. In Babylonian the Umlaut (caused be "sharp laryngeals") affects every preceding or following a and causes shift into e. This is one of the differences between Babylonian and Assyrian.

P: At the ends of 11. 3, 4 and 6a are erasures. In 1. 3 the ma seems to be erased. In 1. 6a I read an-nu-um-ma as-su with an erasure following. The an is certain. Your translation "now (?)" is hardly correct. The particle should be (and is almost everywhere else) a-nu-um-ma. The spelling with nu points to a form of the demonstrative pronoun.

The chief passage for tallum in my omen texts is YBC 4629 II 48ff. There, one finds omina which begin šumma ta-al-lu. If one does not know what it is, one can hardly learn it from there.

Since I have not yet made out slips of all texts, I can quote at present only one passage for tarahhum (perhaps there is only this one). Iit is YBC 4678 IV 51ff.: šum-ma mar-tum (52) lipi-a-am (53) ta-ra-ha-a-sa u-ka-al-la "supposing the gall-bladder, its two tarahhu hold "fat".

[?]: In 1.13 of the obverse can be no doubt as to the reading ne-pu-šu. The pu is perfect, i. e. contains four Winkelnaken. Obviously the photograph did fool you.

Cordially yours

\section{YUL, Goetze to Neugebauer and Sachs 1943/01/25}

January 25, 1943

Dear Neugebauer:

Here enclosed you will find the statement on the "dialects" of the mathematical tablets which I promised you some time ago. At the same time I am returning the pages of your manuscript which you so kindly placed at my disposal.

Not that I am entirely satisfied with the result. You will see that I felt completely to attempt some grouping of the texts. On this point I expect your criticisms. It is my feeling that I rather encroached on your domain. I would feel much better, if you could be persuaded to handle this subject in a special chapter which should precede mine. As it is, I could give only some hints in footnotes. You have expressed yourself the intention of doing some grouping at the head of your glossary. And I think the subject calls for some fuller treatment.

Otherwise, I think, it turns out neatly enough.

Expecting your reaction,

cordially yours

YUL, Neugebauer and Sachs to Goetze 1943/02/17 (the letter is erroneously dated 1942)

Providence, February 2, $1942^{\text {sic }}$ 


\section{Dear Goetze,}

We still owe you a detailed reaction to your contribution to MCT in addition to the short words of thanks we have already sent you. We should have done this long ago, but we were both pretty tired out, partly from work on MCT (preparing the final manuscript and copying the texts) and stupid teaching in ever increasing amount. Fortunately enough, Brown University ran out of oil, and this gave us a chance to recover and to write to you under less unreasonable conditions.

First of all, we must emphasize that we are very glad that we asked you for this contribution, which brings a very interesting new element into our own discussion. As you know, we are unable to establish any local distinction in our material - an attempt (MKT 387f.) to localize the "Series Texts" at Kish must now be abandoned because new evidence gained from analysis of an MCT text shows that sig $_{4}$ never means "volume", but always "brick(s)". It is therefore of great interest to learn that a clear "southern" group can be isolated. Unfortunately, we cannot contribute anything to this view of yours from the point of view of content. Our arrangement (A, B, C, D, etc.) is purely arbitrary according to content e.g., geometrical problems, irrigation problems, etc. The more material we get, the more we begin to realize to how great an extent we are at the mercy of the accidental character of the excavation and preservation of our texts. Grouping which seemed to be quite reasonable in MKT (e. g. "series texts") disappear more and more. All we can say at present is that the content of the OldBabylonian mathematical texts is so homogeneous and uniform that from this point of view one cannot make any classification with regard to origin or time (of course, the clear distinction from Seleucid material remains). We therefore intend to incorporate your contribution with no essential alterations as a separate chapter at the end of the large section dealing with problem texts. As the title of this chapter we suggest: "The Akkadian Dialects of the Old-Babylonian Mathematical Texts. By A. Goetze". On the title page of MCT we would like to mention your name in the form "MCT by O.N. and A.S. with a chapter by A.G." Please let us know if you are in agreement.

We might suggest a few minor alterations to conform with our own manuscript. We will send you the final copy of your chapter with our suggestions incorporated when it is typed; at that time, you will have the opportunity of approving all details or making any alteration that you may wish.

We are slowly approaching the end of our work -- provided that you don't discover new material. In the meantime, we wish to repeat our warmest thanks for your manuscript, which will contribute considerably to the rounding out of MKT and MCT.

Cordially yours

MCT, Inc.

\section{3- Competition with Thureau-Dangin}

\section{YBC, Stephens to Neugebauer 1936/04/03}

New Haven, April 4, 1936

Dear Prof. Neugebauer:

Thureau-Dangin has requested me to send him photographs of eight of the mathematical tablets which you published in transcription, but without the autographed copy, in MKT. 
These are YBC 4668, 4669, 4673, 4695, 4696, 4697, 4698, and 4711. These are eight of the nine texts concerning which you wrote me under date of 28.12.35 that you intend to publish the autographed copies, and that you then had your manuscript practically ready for the press. In my letter of December 6, 1935 I stated to you that, "our policy is to allow no one to study a tablet which has been assigned for publication, without the consent of the one to whom it had been assigned, until after it has been published." Th-D writes, "je n'ai nullement l'intention de publier ces photos. Je désire seulement être en mesure de contrôler les copies ou transcriptions de Neugebauer ». Nevertheless, it becomes my duty to refuse his request, unless you give your consent to his having the photos of the above mentioned tablets. The decision is in your hands; please let me know your pleasure as soon as possible.

Yours sincerely,

Ferris J. Stephens

Acting Curator.

\section{YBC, Stephens to Neugebauer 1936/06/16}

New Haven, June 16, 1936

Dear Prof. Neugebauer:

Under date of April 3, 1935 I wrote you to decide whether or not Thureau-Dangin should be given photographs of 8 of the mathematical tablets which you intent to publish in autograph in your Nachtragsheft to MKT. He has stated that he has no intention to publish the photographs, but only wishes to be able to control the transcriptions as already given by you in MKT. I think he feels that he should be permitted to have the photographs. Nevertheless I am bound not to furnish them to him without your consent, because of our policy not to allow any one to study a tablet which has been assigned for publication without the consent of the one to whom has been assigned.

May I hear from you at an early date concerning this matter, and also concerning the progress of your Nachtragsheft?

Yours very sincerely,

Ferris J. Stephens

Acting Curator.

\section{YBC, Neugebauer to Stephens 1936/06/27 (in German)}

Copenhagen 27.6.36

Dear Professor Stephens,

Thank you very much for your letter of the 16 June. Within the next weeks I am going to send off my supplement on the MKT for printing. Unfortunately, I was incapable to work due to illness for an extended period of time and I have only now finished the autographs. Hence, I would be indebted to you if you could refrain from releasing photographs of these texts to $\mathrm{Mr}$. Thureau-Dangin until the publication of my supplement (which is likely to happen this autumn). The texts in question are YBC 4668, 4669, 4673, 4695, 4696, 4697, 4698 and 6504. 
You may be wondering why I am asking you to refrain from releasing the texts at the moment, but I have unfortunately had some very strange experiences with Mr. Thureau Dangin and would prefer to complete my work without his interference. He himself has made some texts from the British Museum, which are a direct extension of my texts, unobtainable to me. Moreover, he is so inclined to beat me at every corner that in return I see no reason to facilitate his run in this race, which he started despite me repeatedly communicating my urge for friendly but factual cooperation.

I hope that I do not cause you any discomfort. Needless to say, I would not like you to understand my message in any other way than as an expression of my personal wish, which is in no way binding to you. Please act solely at your own discretion.

With kind regards and warm gratitude for your courtesy,

Yours respectfully

\section{YBC, Stephens to Neugebauer 1936/07/17}

New Haven, July 7, 1936

Dear Prof. Neugebauer:

I have your two letters of the $18^{\text {th }}$ and $27^{\text {th }}$ of June. I am sorry to learn that you have been hindered by illness, and hope that you have now fully recovered.

Be assured that your wishes will be respected concerning the giving of photographs to Thureau-Dangin. I have allowed him to have photographs of the tablets whose texts you have already published in autographed copy. The rest has been with-held.

In regard to your earlier question concerning YBC 4697 I beg to report that, while it has not been baked in the furnace, it is as clean as it can be made. The surface is badly preserved on both sides, and this accounts for the numerous spots on the photographs. Ne cleaning would do any good at these places for the writing is obliterated. I do not think anything at all can be done to improve the legibility of this tablet.

With kindest greetings,

Yours sincerely,

Ferris J. Stephens, Curator.

\section{YUL, Goetze to Neugebauer 1937/02/14 (in German)}

February 14, 1937

Dear Mr. Neugebauer,

My deepest gratitude to you for sending me the third volume of your mathematical cuneiform texts. It is a worthy extension of your earlier work. Many thanks for this valuable gift.

With surprise and honest regret I have come to know that a certain animosity has developed between Thureau-Dangin and yourself. Personally, I feel it is most unfortunate since I have always treasured Thureau-Dangin and never had the slightest reason to doubt his excellent character. Isn't this a rare case among Assyriologists. It almost seems as if Assyriology ruins one's character! 
It is astonishing how deeply you have acquainted yourself with the Assyriology (of your texts). All reasonable persons will surely forgive minor philological oversights and simply be pleased there are not more of them. Philologists have always been incapable of tackling these texts and thus they must be delighted with what you have done with them.

P. Schaumberger dropped by. He is trying to find astronomical texts in America. I don't know, if he will be successful. The American collections are to a large extent assembled by purchase. However, mathematical and astronomical tablets are extremely rare. I think Chicago has some; maybe one can also expect some in Philadelphia. But unfortunately, a vast quantity of tablets are still stowed in boxes and the chances are that, no one truly knows, what they contain. The museum in Philadelphia would need an Assyriologist solely for the inspection and publication of the tablets.

With kind regards,

Yours

\section{YUL, Neugebauer to Goetze 1938/03/21 (in German)}

Copenhagen, March 21, 1938

\section{Dear Mr. Götze,}

I have just been made aware of the fact that Thureau-Dangin is looking for someone to edit the Mari texts. Could you be so kind as to write to Thureau-Dangin and recommend Oppenheim? After all, he is the ideal man for this job. I would rather avoid doing so and needless to say, I do not wish to be mentioned at all. I suppose Thureau-Dangin is not too fond of me and therefore I dare say that my involvement in the matter would have the opposite effect.

In haste, my best regards,

Your

\section{Appendix B: photos and transliterations}

\section{1- Damaged tablet or damaged photo? YBC4710}

The following pictures show problem 4 on YBC 4710 (obv. col. i, li. 14-24) in the photo used by Neugebauer, the copy in MKT, and the current photo (see Fig. 4).

\begin{tabular}{|ccc|}
\hline [Fig4a $]$ & {$[$ Fig4b] } & {$[$ Fig4c] } \\
$\begin{array}{c}\text { Aaboe-Britton Archives, } \\
\text { folder YBC 4710 }\end{array}$ & $\begin{array}{c}\text { Neugebauer Handcopy, MKT II, } \\
\text { pl. 58 }\end{array}$ & C. Proust Photo, 2009 \\
\hline
\end{tabular}

The following transliteration of YBC 4710 \#4 shows that Neugebauer and Thureau-Dangin used the same blurred photo. The text is, in fact, perfectly preserved, and doesn't require the use of brackets. 

14. a-ša $1\left(\mathrm{eše}_{3}\right) \mathrm{GAN}_{2}$ uš $\check{s} a$
14. eqlum ebel ikîm šiddim
14. a-ša $1\left(e^{2} \mathrm{e}_{3}\right) \mathrm{GAN}_{2}$ uš-ta
15. a-na ba-zi nu-zu
15. mala assuhu ul(a) îde
15. a-na ba-zi nu-zu
16. $\check{s} a ́ \mathrm{u}[\check{\mathrm{s}}-\mathrm{ta} \mathrm{b}] \mathrm{a}-\mathrm{zi}$
16. ̌̌́ ina šiddim uštakil
16. $\quad \operatorname{nig}_{2}$ uš-ta ba-zi
17. KI íb-t[ $\left.\mathrm{ag}_{4} \mathrm{u}\right] \mathrm{s}$ ì-kú
17. itti šapitti šiddim assuhu
17. ki ib $b_{2}-\mathrm{taka}_{4}$ uš $\mathrm{i}_{3}-g \mathrm{gu}_{7}$
18. sag [íb-sìì 1 (eše)] gán (?)
18. a[na pûu]tim $[a \check{s}] \check{s} i$
18. $\quad$ sag-še ${ }_{3} \mathrm{bi}_{2}-\mathrm{il}_{2}$
19. a-š[à (?) K]I (?) šá uš ba-zi
19. eq[lam] ù šá <ina> šiddim assuhu
19. a-ša $\mathrm{u}_{3}$ nig 2 uš ba-zi
20. ì-kú-ma (?)
21. ì-kú u-gù ì-k[ú]
20. uštakil-ma
20. $\mathrm{i}_{3}-\mathrm{gu}_{7}-\mathrm{ma}$
22. $1,48 \mathrm{~d}[\mathrm{irig}]$
21. ì-kú eli ì-kú
23. [š $] a ́$ uš-ta ba-[zi]
22. $1.48 \hat{\imath}[$ ter $]$
24. [u]-gù íb-t[ag 4 u]š $6 \operatorname{dir}[i g]$
23. šá i[na] šiddim as[suhu]
24. [e]li ša[pilti šid]dim 6 îter
21. $\mathrm{i}_{3}-\mathrm{gu}_{7}$ ugu $\mathrm{i}_{3}-\mathrm{gu}_{7}$
22. 1.48 diri
23. nig $_{2}$ uš-ta ba- $[\mathrm{zi}\rceil$

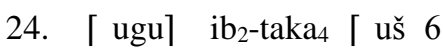 diri]

In the Goetze's collations (notes in Aaboe-Britton Archives, folder YBC 4710 dated February $3,1935)$, it is clear that the text was better preserved than thought by Neugebauer:

[Fig5]

\section{2- Dirty tablet and blurred photo: YBC 4668}

The following pictures show problem 33 on YBC 4668 (obv. col. ii, li. 59-61) in the photo used by Neugebauer, the copy in MKT, and the current photo:

\begin{tabular}{|ccc|}
\hline [Fig6a] & {$[$ Fig6b] } & [Fig6c] \\
$\begin{array}{c}\text { Aaboe-Britton Archives, } \\
\text { folder YBC } 4668\end{array}$ & Neugebauer Handcopy, MKT III, & C. Proust Photo, 2009 \\
& pl. 2 & \\
\hline
\end{tabular}

\section{Neugebauer's transliteration (MKT I, p. 425)}

59. a-[ša $\mathrm{s}_{3} 1\left(\mathrm{eše}_{3}\right) \mathrm{GAN}_{2}$ igi-3-g] $\mathrm{al}_{2}$ uš

60. [igi-4-gal 2 sag $a-n a$ uš ugu sag diri]

61. [a-ra2] 2 e-tab-ma uš sag

Thureau-Dangin's transliteration (TMB, p. 169)

59. eq[lum ebet ikîm šaluš] ti šiddim

60. [rabiat pûtim mala šiddum eli pûtim îteru]

61. [a-ra 2$] 2^{e} \hat{e}$ șip-ma šiddum pûtum

Translation after recent collation (made by $C$. Proust in 2009)

59. a-ša 1 (eše $\left.e_{3}\right) \mathrm{GAN}_{2}$ igi-3-gal 2 uš

60. igi-4-gal 2 sag a-na uš $<$ ugu sag diri $>$ 
61. a-ra 2 2-e tab-ma uš sag

\section{Bibliography}

\section{Abbreviations}

$M C T=$ Neugebauer and Sachs 1945

$M K T=$ Neugebauer $1935-1937$

$T M B=$ Thureau-Dangin 1938

$Y U L=$ Yale University Library

$Y B C=$ Yale Babylonian Collection

\section{Archives}

Aaboe-Britton Archives: currently at the Institute for the Study of the Ancient World, New York University, New York, USA.

IAS Archives: The Shelby White and Leon Levy Archives Center, Institute for Advanced Study, Princeton, USA.

YBC Archives: Yale Babylonian Collection, Yale University, New Haven, USA. 2 folders are used here: Neugebauer 1931-1957, and Sachs 1942-1955.

YUL Archives: Yale University Library, Manuscripts \& Archives Yale University, New Haven, USA. The folder used here is Goetze 1929-1978, MS \# 648, box \# 15.

\section{References}

Di Bella, C., 2010, "From the Shelby White and Leon Levy Archives Center", The Institute Letter Spring 2010, 3; 8 .

Dhorme, E., 1946, Hommage à la mémoire de l'éminent assyriologue François ThureauDangin (1872-1944), Mémoires de la Société Orientale "Ex Oriente Lux" vol. 8 (Leiden: Brill).

Friberg, J., 2000, "Mathematics at Ur in the Old Babylonian period", Revue d'Assyriologie 94, 98-188.

Goetze, A., 1945, "The Akkadian dialects of the Old-Babylonian mathematical texts", chapter 4 of O. Neugebauer and A.J. Sachs (ed.), Mathematical Cuneiform Texts (New Haven: American Oriental Series \& American Schools of Oriental Research).

Goetze, A., 1946, "Numbers idioms in Old Babylonian”, Journal of Near Eastern Studies 5, 185-202.

Goetze, A., 1948, [Review of Neugebauer and Sachs, Mathematical Cuneiform Texts], Journal of Cuneiform Studies 2, 33-37.

Goetze, A., 1951, “A mathematical compendium from Tell Harmal”, Sumer 7, 126-155.

Høyrup, J., 2000, "The finer structure of the Old Babylonian mathematical corpus. Elements of classification, with some results", in J. Marzahn and H. Neumann (ed.) Festschrift für 
Joachim Oelsner anläßlich seines 65. Geburtstages am 18. Februar 1997 (Münster: Ugarit Verlag).

Høyrup, J., 2002, Lengths, Widths, Surfaces. A Portrait of Old Babylonian Algebra and its Kin (Berlin \& London: Springer)

Jacobsen, T., 1946, [Review of Neugebauer and Sachs, Mathematical Cuneiform Texts], Bulletin of the American Schools of Oriental Research 102, 17-18.

Neugebauer, O., 1932-1933, "Zur transcription mathematischer und astronomischer Keilschrifttexte", Archiv fur Orientforschung 8, 221-223.

Neugebauer, O., 1935-7, Mathematische Keilschrifttexte I-III, Quellen und Studien zur Geschichte der Mathematik, Astronomie und Physik (Berlin: Springer).

Neugebauer, O., and A. J. Sachs, 1945, Mathematical Cuneiform Texts (New Haven: American Oriental Series \& American Schools of Oriental Research Original edition).

Goetze, A., 1948, [Review of Neugebauer and Sachs, Mathematical Cuneiform Texts], Journal of Cuneiform Studies 2, 33-37.

Oppenheim, A. L., 1947, [Review of Neugebauer and Sachs, Mathematical Cuneiform Texts], Journal of Near Eastern Studies 6, 126-128.

Proust, C., 2010, "Mesopotamian metrological lists and tables: Forgotten sources", in F. Bretelle-Establet (ed.) Looking at it from Asia: The Processes that Shaped the Sources of History of Science (New York: Springer).

Swerdlow, N. M., 1993, "Otto E. Neugebauer (26 May 1899- 19 February 1990)", Proceedings of the American Philosophical Society 137, 139-165.

Thureau-Dangin, F., 1893, "La comptabilité agricole en Chaldée", Revue d'Assyriologie 3, 118-146.

Thureau-Dangin, F., 1896, "Quelques mots de métrologie", Zeitschrift für Assyriologie und Vorderasiatische Archäologie 11, 428-432.

Thureau-Dangin, F., 1930, "Nombres concrets et nombres abstraits dans la numération babylonienne", Revue d'Assyriologie 27, 116-119.

Thureau-Dangin, F., 1932, Esquisse d'une histoire du système sexagésimal (Paris: Geuthner).

Thureau-Dangin, F., 1936, [Review of Neugebauer, Mathematische Keilschrifttexte I], Revue d'Assyriologie 33: 55-62.

Thureau-Dangin, F., 1937, [Review of Mathematische Keilschrifttexte III], Revue d'Assyriologie 34: 87-92.

Thureau-Dangin, F., 1938, Textes Mathématiques Babyloniens (Leiden: Ex Oriente Lux).

Thureau-Dangin, F., 1939, "Sketch of a history of the sexagesimal system”, Osiris, 7, 95-101.

Veldhuis, N., 1997, Elementary Education at Nippur, The Lists of Trees and Wooden Objects, Ph. D. dissertation, University of Groningen. 